\title{
Phenomenology Study of Nutrition Support in Children with Acute Lymphoblastic Leukemia during Chemotherapy
}

\author{
Dian Estiningtyas'), Bhisma Murti'), Hermanu Joebagio) \\ ${ }^{1)}$ Masters Program in Public Health, Universitas Sebelas Maret \\ ${ }^{2)}$ School of Health Polytechnics, Ministry of Health Surakarta
}

\section{ABSTRACT}

Background: Acute lymphoblastic leukemia in children is a case most often found in children under 15 years with a percentage of $30-40 \%$. According to data from the medical record installation of Dr. Kariadi Hospital, the number of children under 15 years old with LLA hospitalized during 2015 - 2019 was 526 cases with a death rate of 69 patients. The treatment process is quite complex because it takes a long time and requires active involvement between health workers and parents. This study aims to describe the nutritional support of children with Acute Lymphoblastic Leukemia (ALL) during the chemotherapy process in Semarang Subjects and Method: This was a qualitative study with a phenomenological perspective. The study was conducted at Dr. Kariadi Hospital, Semarang. The sample was taken by using purposive sampling. The tools used in this study were cellphones, interview guides and field notes guidelines. The data collection technique is by interview, observation and document analysis. Data analysis was performed using the Analysis Interactive model of Miles and Huberman.

Results: This study shows 5 themes, namely a description of the subject's condition, physio- logical problems during the chemotherapy process, nutritional support during the chemotherapy process, nutritional knowledge, and socio-economics.

Conclusion: Nutritional support for children with Acute Lymphoblastic Leukemia (ALL) during the chemotherapy process is still not optimal. This is influenced by physiological problems that arise during the chemotherapy process and also because of the characteristics of each child, the limited knowledge of the companion about the concept of a healthy diet by choosing the right food ingredients and the socioeconomic factors of the participants who claim to be limited in providing healthy and nutritious intake.

Keywords: nutritional support, acute lymphoblastic leukemia, chemotherapy

\section{Correspondence:}

Dian Estiningtyas. Masters Program in Public Health, Universitas Sebelas Maret. Jl. Ir. Sutami 36A, Surakarta 57126, Central Java. Email: dianesttyas@gmail.com. Mobile: +6281514465646.

\section{Cite this as:}

Estiningtyas D, Murti B, Joebagio H (2020). Phenomenology Study of Nutrition Support in Children with Acute Lymphoblastic Leukemia during Chemotherapy. J Matern Child Health. 05(05): 537-548. https://doi.org/10.26911/thejmch.2020.05.05.08.

(i) (2) Journal of Maternal and Child Health is licensed under a Creative Commons Attribution-NonCommercial-ShareAlike 4.o International License.

\section{BACKGROUND}

Cancer is a non-communicable disease that is a major health problem, both in the world and in Indonesia, which is the second cause of death after cardiovascular disease. According to the WHO report in 2017, there were $\mathbf{1 4 . 1}$ million cases and 8.2 million deaths caused by cancer. Cancer cases in children are the main cause of death in children (Rahmawati, Hapsari, and Suryani 2019). One type of cancer that is often found in children is leukemia, in which white blood cells (leukocytes) experience an abnormal increase in numbers in the blood 
and bone marrow so that they are unable to function properly (Stevens et al, 2008).

Acute Lymphoblastic Leukemia or called ALL is a case most often found in children under 15 years with a percentage of $30-40 \%$ (Wolley, 2016). According to data from the medical record installation of Dr Kariadi Hospital, the number of children under 15 years old with LLA who were hospitalized during 2015 - 2019 was 526 cases with a death rate of 69 patients. Based on data from IARC 2017 (International Agency for Research on Cancer), the incidence of leukemia in the world has increased by $13 \%$. The incidence of ALL in children in Singapore is reported to be 3.78 cases per 100,000 children, where the peak incidence is at the age between 3-5 years (Agnes, Widjajanto, Damayanti, 2019).

Meanwhile, according to data from the National Cancer Institute of the United States during 2013-2017, the incidence of new cases of leukemia in children 0-19 years was 4.7 per 100,000 children per year with a mortality rate of 0.6 per 100,000 children per year. The problem of cancer in children is also a big enough problem in Indonesia because based on the 2018 Global Cancer Observatory data in 2018, deaths from leukemia reached 11,314 people. These results are in line with the Malaysian Cancer Registry data, where the top 5 causes of death due to cancer in children are $48 \%$ leukemia, $15 \%$ brain and nervous system, 9.1\% lymphoma, $6.0 \%$ bone and cartilage and $3.8 \%$ malignant neoplasm of eye and adnexa ( Sulistiowati, Lolong, and Pangaribuan 2016).

In general, cancer patients suffering from leukemia come to the hospital in a state of malnutrition. Cancer in children is different from adults in that in adults, it can be prevented, while in children it tends to be, it cannot be prevented because it is related to genetic factors. However, a healthy lifestyle and diet must be taught from an early age in order to avoid various types of cancer that arise in adulthood (Caesandri and Adiningsih 2015). Treatment of cancer in children includes chemotherapy, radiation therapy, bone marrow transplant, cryotherapy and peripheral blood stem cell transplantation. Treatment of children suffering from cancer requires a long, continuous and regular process. The treatment carried out causes discomfort such as physical problems, namely nausea, vomiting, sores in the oral cavity, hair loss, and peripheral nerve disorders such as numbness and tingling in the fingers and toes (Ginn et al. 2018).

The results showed that children with cancer will experience physical problems as a result of the physiological impact of treatment, such as frequent alopecia (hair loss) $80 \%$, canker sores $63.3 \%$, nausea $56.7 \%$, vomiting $53.3 \%$, fever $53.3 \%$ and diarrhea 10\% (Herfiana 2017). In addition, a cancer verdict can cause fear, anxiety, and stress which stimulates the catecholamine hormone, a hormone that can reduce appetite (anorexia). A decrease in appetite is followed by a drastic weight loss that leads to cachexia, which is an imbalance between intake and increased nutritional needs. Prolonged cachexia will lead to malnutrition. $20-50 \%$ of childhood cancer sufferers experience nutritional problems, one of which is malnutrition. Malnutrition in cancer patients apart from the cancer itself, is also a side effect of medical therapy (Loeffen et al. 2015).

Assessment of nutritional status in patients with malignancy is important because malnutrition can reduce treatment tolerance, increase the incidence of infection $(\mathrm{p}<0.001)$ and decrease the survival rate (Barr and Mosby 2016). Poor nutrition is associated with impaired immune response which consists of impaired phago- 
cyte function, cytokine production, antibody secretion and the complement system. Research conducted by Fengyan 2018 proved that the Overall Survival (OS) of LLA in children with malnutrition within 5 years was $26 \%$ while in good nutrition it was $59 \%$ ( $\mathrm{p}<0.001)$ and mortality in malnutrition was 1.8 times greater than good nutrition ( $\mathrm{p}<0.001)$. Research related to the nutritional status of leukemia patients in children conducted by Noor (2009) shows that the prevalence of malnutrition is proven to be higher in children with newly diagnosed leukemia, so the nutritional status of children with leukemia must be monitored regularly to avoid infection and complications during undergoing treatment. Children with cancer are at high risk for malnutrition and growth problems. A study of children with cancerous malignancies who were being treated at a pediatric oncology hospital reported that children suffering from ALL were three times more likely to experience malnutrition than children who were healthy / had no history of cancer (Loeffen et al. 2015).

Previous research has shown that ALL children with malnutrition or poor nutritional status have a shorter survival than children who are well nourished, even if the frequency of hospitalization is more frequent in all LLA children who have poor nutritional status (Rachmawati 2014). Preliminary research conducted at the Medical Records of Dr. Kariadi Hospital Semarang from 20 October 2019 to 20 November 2019 shows that data from 2015 - 2019 states that there are 526 patients with a mortality rate of 69 patients in children under 15 who suffer from acute lymphoblastic leukemia ( ALL). Seeing the number of children suffering from cancer, especially Acute Lymphoblastic Leukemia (ALL) and the absence of studies that discuss specific nutritional support for children with Acute
Lymphoblastic Leukemia (ALL), researchers are interested in conducting research on nutritional support for children with Acute Lymphoblastic Leukemia (ALL) in Dr. Kariadi General Hospital.

\section{SUBJECTS AND METHOD}

\section{Study Design}

This research is a qualitative research with a phenomenological perspective which was conducted at RSUP Dr Kariadi Semarang from October 2019 to March 2020.

\section{Population and Sample}

Sampling in this study was carried out using purposive sampling technique which was chosen because it was considered to know the information and the problem in depth, namely the parents (closest people) with children with Acute Lymphoblastic Leukemia at Dr Kariadi Hospital Semarang.

\section{Study Instrument}

The research instruments used for data collection were cell phones, interview guides and field notes guidelines. The data collection techniques are interviews, observation and document analysis.

\section{Data Analysis}

Retrieval of data by in-depth interviews, observation and document analysis Data analysis was carried out using the Analysis Interactive model from Miles and Huberman which divided the analysis into three parts, namely: data reduction, data presentation, and drawing conclusions or data verification.

\section{RESULTS}

Kariadi Hospital is a class A hospital which is a referral hospital for the Central Java region which was established on September 9, 1925. Kasuari Installation is an Integrated Cancer service building that specifically provides outpatient and inpatient services for cancer patients equipped with 
modern standard infrastructure, international operations since April 2018.

Participants are people who are considered to know the information and problems faced in depth and are willing to provide reliable information to become a source of data. In this study, the participants were divided into two, namely the main participants and the supporting participants. The main participants in this study were the parents (closest people) with children with Acute Lymphoblastic Leukemia at the Kasuary Installation at Dr Kariadi Hospital, namely 7 people. Supporting participants in this study were nurses at the Kasuari Installation at Dr Kariadi Hospital.

Based on the information obtained from the participants, the children diagnosed with ALL were between 3-12 years old with 4 boys and 3 girls. The chemotherapy target for these children is between 102 and 110 times. The initial complaints of the subject included swollen feet, fever, low $\mathrm{Hb}$, pale, low platelets, frequent sweating, sore hands and feet, frequent itching backs, and high leukocyte levels. After the diagnosis was made, the participants received information from the doctor regarding the process of determining the type of treatment which contained a chemotherapy schedule (including the induction phase, the consolidation phase, and the maintenance phase) and the drugs given during the chemotherapy process. Some of the problems experienced by the subject during the chemotherapy process, including nausea, vomiting, decreased appetite, decreased $\mathrm{Hb}$ and platelets, fatigue, alopecia, susceptibility to infections, easy fever, and mouth sores. Several nutritionrelated problems during the chemotherapy process indirectly affect the amount of intake, nutritional status and quality of life of the subject. In addition, from the partici- pant information, it was also found that 2 out of 7 subjects had less nutritional status and 1 in 7 subjects had more nutritional status. A decrease in the nutritional status of the subjects was felt after the initial diagnosis of ALL and the chemotherapy process was started. This is due to the limited intake of subjects caused by the effects of the chemotherapy process, so that the food consumed is not sufficient for daily needs. The assumptions of the researchers regarding the nutritional support for subjects during the chemotherapy process are still considered less than optimal. Apart from being influenced by physiological problems that arise during the chemotherapy process as well as the characteristics of each child, limited knowledge of companions, lack of educational counseling regarding the role of nutrition and diet from related health workers and socio-economic factors of participants who claim to be limited in providing healthy intake. and nutritious for the subject.

Regarding nutrition education, information was obtained that the participants did not understand the concept of a healthy diet and the foods that need to be consumed or avoided for the subject during the chemotherapy process. In addition, the participants also admitted that they really need nutrition education and assistance for health workers related to nutrition education and counseling to help anticipate children's physiological problems during the chemotherapy process. Based on the results of the interview, it was found that the patient and family need health education. Health education is mainly about the selection of food ingredients, providing effective nutrition and how to overcome problems that arise during the treatment process (chemotherapy). In addition, coordination from various parties such as the participants as the subject's companion and 
the related health workers for the realization of proper and effective nutritional care for ALL child patients to optimize the work of drugs during the therapy process is also needed. Although during the chemotherapy process drugs that stimulate appetite will be given, basically choosing the right food ingredients is the main thing in order to meet nutritional needs and avoid continuing complications of disease in children with ALL.

The socio-economic condition of the participants while accompanying the subject for treatment at Dr Kariadi Hospital was helped by BPJS. Although this is not the whole thing, because there are some expenses that use personal costs such as transportation costs, housing costs, food costs and some medicine costs that are not covered by BPJS. In addition, some participants admitted to experiencing financial difficulties and could no longer work as freely as they used to because they had to care for and accompany the subject during the treatment process.

\section{DISCUSSION
a. Description of Subject State}

The results of the study that have been obtained from interviews with several participants showed that the age of the pediatric patients with ALL in this study ranged from 2 - 12 years with the initial diagnosis age $<4$ years being 5 children with a comparison of 4 boys and 3 girls. This is in line with the analysis conducted by Shahnawaz (2019) which shows that the incidence of leukemia is higher in the age range of children between 1-15 years and with a 2: 1 ratio between boys and girls.

In the initial diagnosis process, pediatric patients experience several symptoms, including swollen feet and pain that makes it difficult to move, fever, low $\mathrm{Hb}$, pale, low platelets, frequent sweating, sore hands and feet, frequent itching backs, high leukocytes and weakness. Leukemia is a blood cell malignancy originating from the bone marrow, characterized by the proliferation of white blood cells with the manifestation of abnormal cells in the peripheral blood. In leukemia, there is a disturbance in the regulation of leukocyte cells. Leukocytes in the blood proliferate uncontrollably and their function becomes abnormal. Because of this process, other functions of normal blood cells are also disrupted, causing several symptoms of leukemia, as experienced by these pediatric patients at the beginning of the diagnosis (Tumbuan et al. 2015)

Other symptoms such as pain in the bones and joints are caused by the infiltration of the bone marrow by leukemia cells. Fever and profuse sweating are symptoms of hypermetabolism. Oral, upper and lower airway infections, cellulitis, or sepsis. This infection often recurs due to neutropeni or a reduced number of neutrophils. Skin bleeding (petechiae, atraumatic ecchymosis), gum bleeding, hematuria, gastrointestinal bleeding, brain hemorrhage, where these bleeding occurs due to a lack of platelet count (American Cancer Society 2018).

\section{b. Child Physiological Problems During Chemotherapy}

The effective management of leukemia therapy in children with leukemia is chemotherapy. After the diagnosis is made, the participants get information from the doctor regarding the process of determining the type of treatment which contains a chemotherapy schedule which includes the induction phase, central nervous system (CNS) prophylactic therapy, the consolidation phase, and the maintenance phase, as well as the drugs given during the chemotherapy process (Patrick 2015). The length of the child's chemotherapy process based 
on information from participants in this study was between 102x - 106x, which means that it was carried out around $2-3$ years (Kaplan 2019).

Treatment in the induction phase is started and lasts 4 to 6 weeks. The main drugs used for induction are glucorticoids (dexamethasone or prednisone), plant alkaloids (vincristine), and the asparaginase enzyme (Sami, 2020). This drug immediately functions to destroy leukemia cells, with minimal organ toxicity and minimal disturbance of normal hematopoesis. Modern chemotherapy and supportive therapy show that $97-98 \%$ of children achieve complete remission. A perfect remission is achieved, that is, if the leukemia cells are no longer found morphologically, then the next goal is to continue the destruction of the lymphoblasts to a level that corresponds to the recovered state (Marischa 2017).

Management of the CNS consists of prophylactic therapy via intrarecal chemotherapy with methotrexa, cytarabine, and hydrocortisone. Sometimes methotrexa and cytarabine can be injected intrathecally as a single agent. Due to concerns about the side effects of cranial irradiation, this therapy is only used in high-risk patients. Furthermore, consolidation therapy is carried out after complete remission has been completed, consolidation therapy is carried out to remove remaining leukemia cells. This therapy is followed by delayed intesification therapy to prevent the appearance of resistant leukemia clones. Drugs that are usually given at this stage are L-asparaginase, high or medium doses of methotrexa, cytarabine, vincristine, and mercaptopurine for several months (Wong, 2009). Maintenance therapy was started after the induction and consolidation therapy was completed and worked well to maintain remission, further reducing the leukemia cell count. This therapy lasts intensively for 2 - 3 years. This is intended to kill blast cells while maintaining the patient's immune system. The drug commonly used in this phase is mercaptopurine (6 MP), which is given daily with weekly doses of methotresa. Prednisone and vincristine are also often given because they help reduce the recurrence rate (Patrick 2015).

Chemotherapy aims to kill cancer cells with various types of drugs (antineoplastic agents) which can be given orally, intravenously, intramuscularly, subcutaneously, or intrathecally (through the spinal cord). Chemotherapy drugs attack cells that are dividing rapidly, which is why chemotherapy drugs fight cancer cells. But other cells in the body, such as cells in the marrow, lining of the mouth, stomach and intestines, and hair follicles also divide rapidly so that this chemotherapy drug also attacks these normal cells so that it has an impact on several physiological problems felt by patients with ALL children. including hair loss, nausea and vomiting, decreased appetite, mouth sores, and diarrhea. In addition, chemotherapy drugs also suppress the bone marrow so that cell production in the bone marrow decreases, one of which is platelets. Platelets in the body have a role to help stop bleeding by replacing damaged blood cells and helping blood cells to clot. If the platelet count is insufficient, bleeding, or bruising may occur. Thrombocytopenia occurs due to bone marrow compression. The storage compartments in the bone marrow can supply mature cells to the peripheral bloodstream for 8 to 10 days. Thrombocytopenia can cause children to have small spots on the skin, vomiting blood, bleeding in the gums and nose (Brandalise et al. 2016).

Nutrients affect the speed at which the body processes or eliminates drugs, for example, methotrexate inhibits folate meta- 
bolism. Potassium and magnesium homeostasis is altered by cyclosporne which requires replenishment of nutrients due to serum depletion. In addition, long-term use of glucorticosteroid drugs can cause hyperglycemia, fluid retention, weight gain (fat mass) which results in changes in body composition, electrolyte abnormalities, and increased needs for calcium, zinc, vitamin C and Vitamin D (Zalina et al. 2009)

\section{c. Nutritional Support during the Chemotherapy Process}

Based on information from participants in this study, the physiological problems caused by the side effects of the chemotherapy process caused nutritional intake in children to decrease both in terms of quality and quantity of food. It is feared that this will lead to further complications of the disease and affect the effectiveness of the chemotherapy treatment process. Food has an important role in the early diagnosis of cancer patients, implementing treatment, until healing. In cancer patients, nutritional needs increase due to the malignancy process. In addition, treatment with surgery, radiotherapy and chemotherapy will be more effective if the patient is in a good nutritional status (Pillay, Kunneke, and Solomons 2017).

Food management in cancer patients can increase body weight and body protein even though it cannot restore complete nutritional status. However, this situation will reduce the patient's susceptibility to infection and reduce symptoms due to side effects of treatment so that treatment can take place to completion. This is in line with the 2020 study which states that each age group of children has different nutritional needs for development and growth as well as to increase tolerance to treatment, reduce symptoms of the effects of toxicity and improve survival. In addition, a 2018 study suggests that children with leukemia who undergo treatment from the physical health dimension have a poor quality of life and a 2014 study shows that there is a relationship between children's nutritional status and the frequency of hospitalization of pediatric leukemia patients at Dr. Moewardi Hospital (Rachmawati 2014).

Nutritional support is part of supportive therapy in cancer. The aims of nutritional support focus primarily on the potential effects on improving the patient's quality of life. Adequate nutritional conditions are associated with a good prognosis. Nutrition is part of the process of life and development of children, so that the fulfillment of nutrition in the process of healing the disease is needed to optimize the success of cancer therapy in children and reduce the risk of ongoing complications. This is in line with Sami's (2020) research which contains nutritional considerations during cancer treatment, including; 1) careful food handling; 2) avoid sugar; 3) focuses on immune-boosting foods; 4) following a restricted diet (a diet dense in nutrition but low in carbohydrates, restrictions on sugar and salt, a diet low in saturated and trans fats); 5) considering other parameters, attention is paid to age, sex, body weight and height to take into account the total energy requirements (Khatib and Omar 2020).

Nutritional support cannot be separated from the role of parents, especially mothers in caring for ALL patients. In this case, the family has a role, in addition to assisting pediatric patients from a psychological side, it is also related to providing nutritional support for children with leukemia during the treatment process. Families must realize the importance of motivating cancer sufferers to eat foods that they can receive. According to Sheridan (2008), the role of mothers in the family is to fulfill physiological and psycho- 
logical needs, the role of mothers in caring for and taking care of the family patiently, lovingly and consistently. A mother should have knowledge about ALL disease and nutritional needs that should be consumed by ALL patients. With good nutrition, it is hoped that the child's condition will improve and be able to undergo chemotherapy appropriately.

Cancer and its treatment can affect energy and protein intake. Energy imbalances underlie the development of malnutrition in every disease, including cancer. This imbalance is the result of some combination of reduced intake, decreased absorption (including malabsorption), and increased demand. In addition, there are changes in the metabolism of fat, carbohydrates and protein. These changes include increased lipid breakdown resulting in reduced lipid storage, and changes in carbohydrate metabolism, resulting in energy loss. The end result is weight loss and loss of muscle mass manifesting as malnutrition. In previous studies it has been reported that children with cancer will have signs and symptoms of malnutrition at some stage in the course of the disease in up to $50-60 \%$ of cases, but this frequency can vary according to the type of malignancy and based on studies in developed or developing countries. where there has been an increasing frequency of nutritional changes. It should be noted that studies of the prevalence of malnutrition in children with cancer are determined by nutritional status at the start of diagnosis, this is important because it builds on the potential impact on patient development before treatment is started (Barr and Mosby 2016). Based on the description above, it can be concluded that the nutritional support of children with leukemia is influenced by several factors, including the characteristics of the child, knowledge of accompanying nutrition, the level of malignancy of the disease and the economic capacity (purchasing power) of the parents of children with leukemia in providing daily nutrition which is good and right.

\section{d. Nutritional Knowledge}

Based on participant information in this study, participants do not understand the concept of a healthy diet and foods that need to be consumed or avoided for subjects during the chemotherapy process. In addition, participants claimed to have limited knowledge regarding children's nutritional needs during the chemotherapy process. Participants needed nutrition education and assistance for health workers related to nutrition education and counseling to help anticipate children's physiological problems during the chemotherapy process. This is in line with research by Huda (2012) which states that eating habits can affect a person's quality of life. The role of mothers should have sufficient knowledge about nutrition to ensure the selection of good and appropriate food ingredients to optimize the success of the leukemia treatment process in children. In addition, according to Ronald's 2019 study, appropriate interventions in the form of awareness of nutritional support and therapeutic food are needed for pediatric patients with ALL to control the level of risk of morbidity and mortality during therapy. Emma's 2019 research also reported that pediatric patients with cancer consumed a limited variety of foods both in quality and quantity where 13 studies showed less optimal fruit and vegetable intake during the treatment process.

The diet given to ALL patients is a balanced diet according to the state of the disease and the child's acceptance, preventing or inhibiting excessive weight loss, reducing nausea, vomiting, and diarrhea. The things that the companion should pay 
attention to in providing nutritional intake are: 1 . The type of food or diet given should pay attention to appetite, changes in soy sauce senses, feelings of fullness, nausea, weight loss, and the consequences of treatment; 2. Avoid foods or drinks that stimulate coughing, for example oily foods, acidic foods, food coloring, MSG; 3. According to the patient's circumstances, food can be given in the form of solid food, liquid food, or a combination. For solid food, it can be in the form of ordinary food, soft food, or crushed food; 4. If there is difficulty chewing or swallowing, drinking using a straw, food or drink is given at room temperature or cold, the form of food is filtered or liquid, avoid foods that are too acidic or salty (Khatib and Omar 2020).

\section{e. Social Economy}

Friedman (1998) wrote several forms of family support, one of which is financial support. Financial support is related to the costs incurred by the family for treatment or care in supporting health, including in the form of meeting the needs of food intake, nutrition and clothing for sufferers (Anggraeni, 2010). Based on participant information, the participant's economic condition while accompanying the subject for treatment at Dr. Kariadi was assisted by BPJS. Although not as a whole, because there are some expenses that use personal costs such as transportation costs, housing costs, food costs and some drug costs that are not covered by BPJS. Based on this information, the researchers concluded that while accompanying the subject for treatment, the participants had limited time to work to earn money because of the full schedule in accompanying the subject during the treatment process, so that in this case the participants admitted that they were limited in providing and fulfilling some of the needs the subject needed, including nutritional needs good and appropriate during the chemotherapy process. This is in line with Suzy's (2018), which contains effective ALL care that requires spending on therapy and requires subsidies so that the patient's family can pay the necessary contributions for adequate care, such as funds for the patient's and their families' living needs and the provision of shelter during treatment. The study was conducted in low to middle income countries with the conclusion of 200 patients with ALL children, 23\% died during the treatment process, $27 \%$ relapses where $78 \%$ relapses occurred in less than 5 years. From this study, the researchers assumed that economic factors had an effect on the success rate of treatment of patients with ALL children (Abdelmabood et al. 2020).

Family support is a relationship process in the form of attitudes, actions, and family acceptance of its members that are supportive and provide help to its members (Friedman, 2010).

Family support is a very important factor to motivate and increase the spirit of life for cancer patients (Sari, 2012). Frahm (2002) and Sari (2012) explained that family is the best friend for cancer sufferers to both struggle with their disease. In ALL patients, nutrition is needed to support the success of treatment.

The relationship between the participant and the subject is well established, because the subject is always accompanied by the participant during the treatment process. All participants showed closeness to the subject, this can be seen from a good and affectionate way of communicating between the subject and the participants. Meanwhile, the relationship with peers based on participant information, namely among the 3 subjects rarely played with other subjects and more often spent time playing alone. This is consistent with Katz 
(2010) which states that children with leukemia have less social interaction when playing with their peers compared to healthy children. In addition, Vannata's study (2010) explains that children suffering from leukemia have difficulties in social functioning, the differences between cancer and healthy children do not show any adjustment with peers, but instead show withdrawal (social isolation). Based on the results of the study, it can be concluded that nutritional support for children with Acute Lymphoblastic Leukemia (ALL) during the chemotherapy process is still considered less than optimal because it is influenced by physiological problems during the chemotherapy process, the characteristics of each child, limited knowledge of companions and participants' socioeconomic factors who claim to be limited in terms of chemotherapy and provide a healthy and nutritious intake for the subject. In addition, parents admit that they need nutrition education and assistance for health workers related to nutrition education and counseling to help anticipate children's physiological problems during the chemotherapy.

\section{f. Limitation of the study}

This study only presents data based on information provided by informants through in-depth interviews with people closest to ALL child patients and room nurses. At the time of the study, there were 2 patients who died, but because this study was partly conducted online in the midst of a pandemic, the information related to the cause of the patient's death was unclear.

\section{AUTHOR CONTRIBUTION}

Dian Estiningtyas, Bhisma Murti, and Hermanu Joebagio, collect the data, did data analysis, interpreted the results of analysis, and wrote the manuscript.

\section{CONFLICT OF INTEREST}

We declare that there was no conflict of interest.

\section{FUNDING AND SPONSORSHIP}

This study used personal fund.

\section{ACKNOWLEDGEMENT}

We give our gratitude to Dr. Kariadi Hospital, Semarang, Central Java, that give permission

\section{REFERENCE}

Abdelmabood S, Elsayed A, Boujettif F, Mansour A (2018). Treatment outcomes of children with acute lymphoblastic leukemia in a middle-income developing country: High mortality, early relapses, and poor survival. $\mathrm{J}$ de Pediatria. 96(1): 108-116. https://www.scielo.br/pdf/jped/v96n1/oo217557-jped-96-01-0108.pdf.

Agnes M, Widjajanto PH, Damayanti W (2018). Impact of malnutrition on febrile neutropenia in children with acute lymphoblastic leukemia during induction phase chemotherapy. Paediatrica Indonesiana. 58(6). doi.org/10.14238/pi58.6.2018.298-304.

Almatsier S (2006). Prinsip dasar ilmu gizi. Jakarta: PT. Gramedia Pustaka Utama.

American Cancer Society (2019). Acute lymphocytic leukemia early detection, diagnosis, and types. Cancer.

Barr RD, Mosby TT (2016). Nutritional status in children and adolescents with leukemia: An emphasis on clinical outcomes in low and middle income countries. Am J. 21(4). doi.org/10.1080/10245332.2015.1101968.

Barr RD, Stevens MCG (2019). The influence of nutrition on clinical outcomes in children with cancer. Pediatr Blood 
\& Cancer; 67(3). doi.org/10.1002/pbc.28117.

Bauer J, Jürgens H, Frühwald MC (2011). Important aspects of nutrition in children with cancer. Advances in Nutrition. 2(2): 67-77. doi.org/10.3945/an.110.000141.

Behrman (2004). Nelson Textbook Of Pediatrics. 17thed Philadelphia

Brandalise SR, Viana MB, Pinheiro VRP, Mendonça N, Lopes LF, Pereira WV, Lee MLM, Pontes EM, et al. (2016). Shorter maintenance therapy in childhood acute lymphoblastic leukemia: The experience of the prospective, randomized Brazilian GBTLI ALL-93 protocol. Front Pediatr. 4: 110. doi: 10.3389/fped.2016.00110.

Cooper SL, Brown PA (2015). Treatment of pediatric acute lymphoblastic leukemia. Pediatr Clin North Am. 62(1): 6173. doi:10.1016/j.pcl.2014.09.006.

Creswell JW (2007). Research design quantitative and qualitative approach. Philadelphia. Sage Publication.

Edward H (2009). Hematology basic principles and practice. Philadelphia: Chuschill Livingstone Elsevier

Fianza PI (2009). Leukemia limfoblastik akut dalam: Buku ajar ilmu penyakit dalam jilid II (Acute internal lymphoblastic leukemia: Internal medicine textbook volume II). Edisi 5. Jakarta: Interna Publishing

Goddard E, Cohen J, Bramley L, Wakefield CE, Beck EJ (2019). Dietary intake and diet quality in children receiving treatment for cancer. Nutr Rev. 77(5): 267-277. doi: 10.1093/nutrit/nuyo69

Kadir AAK, Hasan JG, Aldorky MK (2017). Nutritional assessment of children with acute lymphoblastic leukemia. Imedpub Journals. 5(128). doi: 10.21767/2254-6081.1000128.
Khatib S.E., Omar M. (2020). Nutritional Considerations in Childhood Acute Lymphoblastic Leukemia.Cancer and Oncology Research 6(1): 11-25. doi: 10.13189/cor.2020.060102

Ladas EJ (2016). Dietary intake and childhood leukemia: The diet and acute lymphoblastic leukemia treatment (DALLT) cohort study. HHS Public Access. 32(10): 1103-1109. doi: 10.1016/j.nut.2016.03.014.

Loeffen EAH, Brinksma A, Debock GH, Tissing WJ (2015). Clinical implications of malnutrition in childhood cancer patients-infections and mortality. Support Care Cancer. 23(1): 143-50. https://doi.org/10.1007/soo520-014-2350-9.

Molassiotis A, Roberts S, Cheng HL, To HKF, Ko PS, Lam W, Lam YF, Abbott $\mathrm{J}$, et al. (2018). Partnering with families to promote nutrition in cancer care: feasibility and acceptability of the picnic intervention. BMC Palliat Care. 17(1):50. doi.org/10.1186/s12904-018-0306-4.

Moleong LJ (2006). Metodologi penelitian kualitatif (Qualitative research methodology). Bandung: PT Remaja Rosdakarya.

Mosby TT, Barr RD, Pencharz PB (2009). Nutritional assessment of children with cancer. J Pediatr Oncol; 26(4): 186-197. doi.org/10.1177/1043454209340326.

Nafrialdi, Sulistia G (2003). Anti Kanker Dalam: Farmakologi Dan Terapi Edisi 4. Jakarta: Gaya Baru.

Omari AO, Wynaden D (2014). The psychosocial experience of adolescents with haematological malignancies in Jordan: An interpretive phenomenological analysis study. SCI World J. 7. doi.org/10.1155/2014/274036. 
Permono B, Sutaryo U, Windiastuti E (2010). Buku ajar hematologi - Onkologi Anak. Jakarta: Badan Penerbit IDAI.

Polit DF, Beck CT, Hungler BP (2001). Nursing research: principles and method $\left(6^{\text {th }} \quad\right.$ ed $)$. Philadelphia. Lippincott.

Rachmawati F (2014). Hubungan status gizi dengan frekuensi hospitalisasi pasien leukemia limfoblastik akut pada anak prasekolah di RSUD Dr. Moewardi Surakarta (The relationship between nutritional status and the frequency of hospitalization of acute lymphoblastic leukemia patients in preschool children at Dr Moewardi Hospital, Surakarta). Naskah Publikasi Surakarta available at http://eprints.ums.ac.id/26048/13/NASKAH_PUBLIKASI.pdf

Rahmawati E, Gamayanti I L, Setyarini S (2016). Pocket book of anxiety: For parents of children with acute lymphoblastic leukemia. International $\mathrm{J}$ Med Sci,1438. doi: 10.18203/23206012.ijrms20161206.

Reilly JJ, Weir, Mccoll JH, Gibson BE (2003). Prevalance of protein - energy malnutrition at diagnosis in children with acute lymphoblastic leukemia. J Pediatr Gastroenterol, 2003; 8. doi: 10.1097/ooo05176-199908000ooo17.

Rudolph AM (2007). Buku Ajar Pediatric Rudolph: Alih Bahasa (Buku Ajar Pediatric Rudolph: Alih Bahasa). Jakarta: EGC.

Shils EM (2008). Modern nutrition in health and disease. Tenth Edition United States Of Amirica: Lippincott Williams \& Wilkins.

Srivastava R, Pushpam, Dhawan D, Bakhshi $S$ (2015). Indicators of malnutrition in children with cancer: A study of 690 patients from a tertiary care cancer center. Indian J Cancer, 52. Diakses https://indianjcancer.com/article.asp?issn $=0019-509 \mathrm{X} ; \mathrm{year}=20-$ $15 ;=52 ;$ issue $=2 ;$ spage $=199 ;$ epage $=201$ ; aulast=Srivastava.

Supariasa DN (2002). Penilaian status gizi (Penilaian status gizi). Jakarta: EGC.

Tan SY, Poh BK, Nadrah MH, Jannah NA, Rahman J, Ismail MN (2013). Nutritional status and dietary intake of children with acute leukaemia during induction or consolidation chemotherapy. J Hum Nutr. 26(1): 23-33. doi: 10.1111/jhn.12074.

Triarico S, Rinninella E, Cintoni M, Capozza MA, Mastrangelo S, Mele MC, Ruggiero A (2019). Impact of malnutrition on survival and infections among pediatric patients with cancer: A retrospective study. European Eur Rev Med Pharmacol Sci. 23: 11651175. doi: 10.26355/eurrev_201901_17009.

Ward E, Desantis C, Anthony R, Kohler B, Jemal A (2014). Childhood and adolescent cancer statistics. CA Cancer J Clin. 64: 83-103. doi:10.3322/caac.21219. Epub 2014 Jan 31.

Willie J (2013). Buku Ajar Onkologi Klinis edisi 2. Jakarta: Fakultas Kedokteran Universitas Indonesia.

Yayasan Onkologi Anak Indonesia. (2012). October 18 2019. http://www.yoaifoundation.org.

Zalina AZ, Suzana S, Rahman AJ, Aini MY (2009). Assessing the nutritional status of children with leukemia from hospitals in Kuala Lumpur. Mal J Nutr. 15(1): $45-51$. https://pubmed.ncbi.nlm.nih.gov/22691804//. 